\title{
The Influence of an Assistant Application Namely "Quizizz" for Teams Games Tournament toward Students' Learning Outcomes During the Coronavirus outbreak
}

\author{
Luluk Regita Handayani ${ }^{1}$, Nurrohmatul Amaliyah ${ }^{2}$, Zulherman $^{3}$ \\ Universitas Muhammadiyah Prof. DR. HAMKA, Jakarta, Indonesia ${ }^{1,2}$ \\ Universiti Utara Malaysia, Sintok, Malaysia $^{3}$ \\ \{lulukregitahandayani@gmail.com $\left.{ }^{1}\right\}$
}

\begin{abstract}
The technology was intentionally made to make human work more manageable. Which also prevails in education. For example, the usage of Quizizz application to make an evaluation of students' learning easier. This application brings together animation, audio, visuals, and various types of questions to measure student learning abilities. One of the advantages that Quizizz offers is, the questions can be accessed flexibly by students, even outside of the school hours. This feature becomes important, considering the pandemic caused by the Coronavirus outbreak (Covid-19). It makes learning has to be done online, which causes so many aspects that need to be adjusted so that learning can be carried out properly. This study aims to determine the influence of science learning outcomes by using the learning model TGT assistant application "Quizizz" on the fourth-grade students of SDN Cakung Barat 07, East Jakarta. The research method used is a quantitative research method with a Quasi-Experimental design, with purposive random sampling using IV-A as an experimental class and IV-B as a control class. Students' outcomes were measured by 20 multiple-choice questions, which had previously been tested for validity and reliability. This study's requirement test includes the normality test using the Chi-Square test formula and the normality test using Fisher's test formula. Meanwhile, the hypothesis test is using the t-test formula. The result stated that there is no significant influence on students' outcomes by using the learning model TGT-assistant application "Quizizz" on the fourth-grade students of SDN Cakung Barat 07, East Jakarta.
\end{abstract}

\section{Introduction}

Indonesia is continuously developing its education to prepare a higher quality for their next generation. Many things have been done, such as carrying out the curriculum changes. However, many factors affect educational success. Study shows that Indonesia's education system still needs to deal with many struggles [1]. One of the causing problems is the teacher's hesitation by choosing the learning models and the lack of technology involved in the learning process. 
Learning models run a crucial role in the learning process [2]. Learning models can be concluded as conceptual frameworks that embody any materials related to the learning process to maximize its final results, such as steps, methods, classroom management techniques, etc.[3]. There are many types of learning models, such as Cooperative Learning.

Teams Games Tournament (TGT) is suitable to be applied in elementary school. This can be stated because TGT combines learning, games, and tournament within this learning model. Hence, TGT is convenient with fourth-grader general characteristics students. TGT requires all students' involvement during the learning process to cooperate with their teammates and achieve their final goals [6]. TGT learning stages started with the material concept delivered by the teacher, and then the students were divided into several heterogeneous groups. After that, the teacher provides a game that aimed to determine the student's ability to comprehend the learning material. The crucial part of this learning model is the tournament. As their team representative, every student's role is to compete against the other team members whose academically equivalent to theirs, which was previously known by the game results [7].

Nevertheless, the pandemic that occurred all across the world also affected education in Indonesia. The Ministry of Education and Cultural Sciences decided to implement online schools, which raises a new challenge for schools that had never previously implemented an online school service. This policy aims to prevent the high number of students who are at risk of being exposed to Covid-19 [8]. The enforcement of this online school policy makes a learning model that previously planned hardly implemented. The high number of schools that have never had experience with distance-learning has chosen by learning media only limited, such as WhatsApp Group, Zoom, or Google Meet. However, if you consider the several applications offered, the most choice fell on WhatsApp as an application that is free, easy, and most commonly owned by students' parents. The use of Google Meet and Zoom is considered expensive because it spent a lot of internet quota. Moreover, Zoom Meetings application requires complicated procedural rules that are considered very burdensome for both students and parents [9]. However, a helpful application such as Quizizz, which can provide convenience in student learning, is beneficial during this Coronavirus outbreak.

Quizizz is a unique game-based educational application. This application offers several features, just like a game. Such as avatars, music, and interesting animations which can bring a new atmosphere to the student learning evaluation process [10]. The Quizizz application can be accessed through the gadget, with many players simultaneously. This feature simplifies the distance learning process, which indirectly helps online learning. Virtually, the Quizizz application is similar to Kahoot. However, Quizizz can provide more conveniences and advantages. The Quizizz application does not require a big screen, so it is accessible through smartphones. The question in Quizizz application can also be given to students as homework [11]. This is in line with the advantages that are felt to be the most beneficial of this application. That is, the process can be done anywhere, anytime, even outside of student class hours. So that learning can be carried out flexibly, considering the different conditions of students during this pandemic [12].

The main objective of this research is to find out the influence of an assistant application, namely "Quizizz" for Teams Games Tournament toward students learning outcomes on the subject of energy sources in Indonesia.

\section{Methodology}

\subsection{Participant}


This study involves 60 students from two classes that have been designated as research sites in the second year with fourth-grader elementary schoolers at SDN Cakung Barat 07, East Jakarta.

\subsection{Instrument and Procedure}

The type of instrument used in collecting the primary data in this study was the test method. The test method is used to obtain data on students' science learning outcomes. The test used is an objective multiple-choice test. This test was given to both sample classes after treatment with the learning model Team Games Tournament (TGT) and conventional learning. Before being used and given to the two-sample classes, this instrument was first tested to determine its validity (validity test) and how reliable the instrument was (reliability test). A total of 20 questions have been tested for validity and reliability.

The research method used is a quantitative research method that involves a numeric or statistical approach to research design [13]. The quasi-experimental design method is a research design with a control group, but cannot fully function in controlling external variables that affect the experiment [14]. A quasi-experimental design identifies a comparison group that is as similar as possible to the treatment group in terms of baseline characteristics [15]. One type of research design in the quasi-experimental design is the non-equivalent control group posttest-only design. This type of research design only gives treatment to one sample class, while the other class role as a control class and the data collection is obtained through the treatment's final results [16]. In this study, the class designated as the experimental class is class IV-A. Class IV-A is the class to be treated with the TGT learning model. Meanwhile, class IV-B is defined as the control class, which is treated with conventional learning models.

The sample used in this study is a purposive sampling obtained from two classes. Purposive sampling is the sample selection technique based on specific considerations and criteria that have been previously determined by the researcher and is deliberately intended to be used as a sample in the study [17]. This study's prerequisite test used the normality test using a Chi-Squared formula, and the homogeneity test using Fisher's test formula. After obtaining the results of the two prerequisite tests of the analysis and the results that the data from the two sample classes are declared normally distributed and have the same variance, the hypothesis test can be carried out with the t-test formula.

\section{Result and Discussion}

Based on the research that has been done, the result data were obtained from the post-test that was previously given to two sample groups, namely the experimental class and the control class. The experimental and the control classes' data post-test were calculated, and their values were determined as mean, median, and mode to proceed with further calculation.

\subsection{Post-test results for the experimental and control classes}

After the two samples were given the different treatments, the data calculation results were obtained post-test from the experimental and control classes. The data is presented in table form to facilitate reading the learning outcome data from the two sample classes. The 
following is a comparison of the science learning outcomes obtained from the two sample classes of this study:

Table 1. Post-test Results of Science Learning Outcomes

\begin{tabular}{lcc}
\hline \multicolumn{1}{c}{ Aspect } & Experimental class & Control class \\
\hline Highest score & 100 & 100 \\
Lowest score & 60 & 60 \\
Mean & 85,633 & 83,067 \\
Median & 86,227 & 84,000 \\
Mode & 85,750 & 84,700 \\
Standard deviation & 8,416 & 9,169 \\
\hline
\end{tabular}

\subsection{Comparison of the experimental and control class}

Here is presented the comparison data of students' science learning outcomes between the experimental and control classes in graphical form to facilitate the statistical reading.

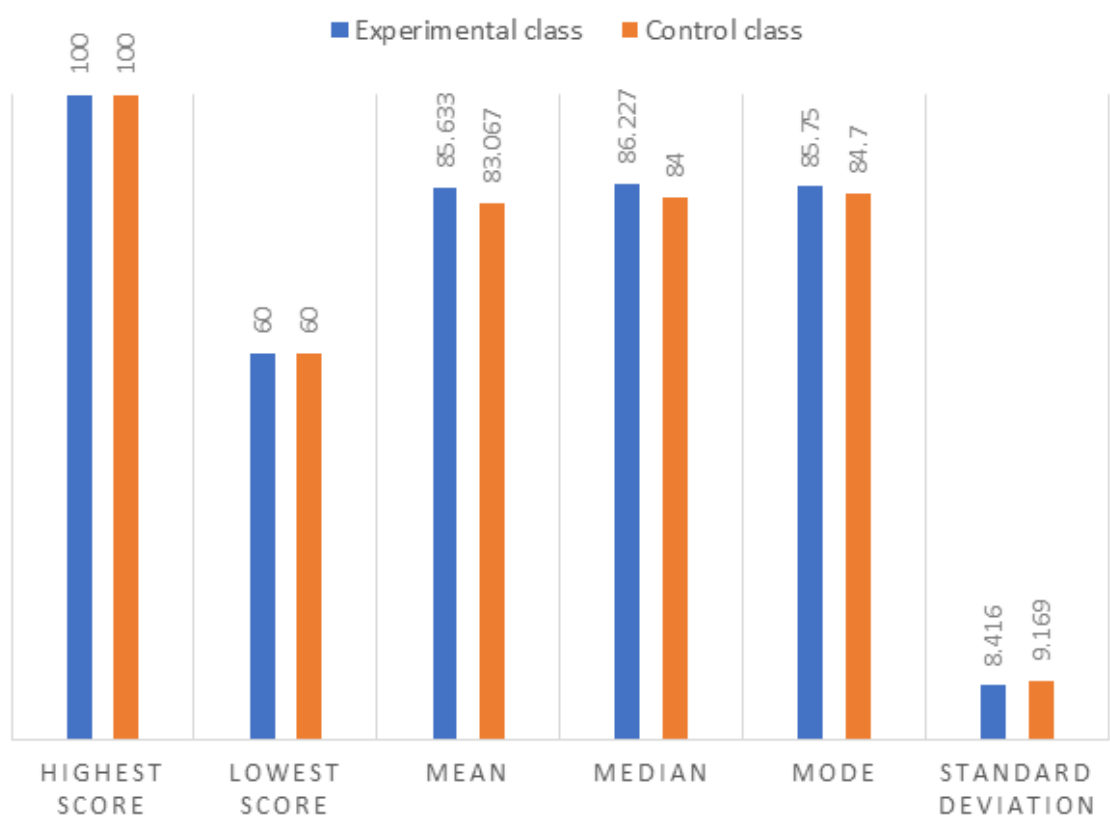

Fig. 1. Comparison of The Experimental and Control Classes

The graph above shows only a slight difference in the students' science learning outcomes of the experimental class and the control class. The data from the students' science learning outcomes are then calculated and their values were determined as mean, median, and mode to proceed with further calculation.

\subsection{Normality test results for the experimental and control classes}

The first step to analyse the data on students' science learning outcomes is to determine whether the data distribution from the two sample classes used in this study is normal or not. 
So, in this study, the normality test was carried out with the Chi-squared formula. The sample can be said to be normally distributed if: Chi - Squared $_{\text {count }}<C h i-$ Squared $_{\text {table }}$.

\begin{tabular}{ccccc}
\multicolumn{5}{c}{ Table 2. Normality Test Results } \\
\hline Category & $\boldsymbol{X}_{\text {count }}^{\mathbf{2}}$ & $\boldsymbol{X}_{\text {table }}^{2}$ & Criteria & Annotation \\
\hline Experimental & 5,502 & 7,815 & \multirow{2}{*}{$X_{\text {count }}^{2}<X_{\text {table }}^{2}$} & NORMAL \\
Control & 3,947 & 7,815 & \\
\hline
\end{tabular}

The table above shows that the data from the two samples used in this study are normally distributed. So, the second analysis prerequisite test can be done-namely, the homogeneity test.

\subsection{Homogeneity test results for the experimental and control classes}

After testing the sample data's normality, the second step is to determine the two samples' homogeneity in this study. The aim is to find out whether the two samples have the same variance or not. In this study, the homogeneity test was carried out using the Fisher test formula. The sample data can be said to be homogeneous if: $F_{\text {count }} \leq F_{\text {table }}$.

Table 3. Homogeneity Test Results

\begin{tabular}{lccccc}
\hline \multicolumn{1}{c}{ Category } & Variances & $\boldsymbol{F}_{\text {count }}$ & $\boldsymbol{F}_{\text {table }}$ & Criteria & Annotation \\
\hline $\begin{array}{l}\text { Experimental } \\
\text { Control }\end{array}$ & 70,832 & 1,186 & 1,861 & $F_{\text {count }} \leq F_{\text {table }}$ & HOMOGENY \\
\hline
\end{tabular}

The table above shows that the data from the two samples used in this study have the homogenous variances.

\subsection{Hypothesis test results for the experimental and control classes}

The hypothesis test can be carried out after the data from the two sample classes have been declared normally distributed with homogeneous variances. The hypothesis test in this study uses the t-test formula. The hypothesis test was carried out to see the influence of using the TGT learning model assisted by the Quizizz application on the fourth-grade students' learning outcomes at SDN Cakung Barat 07, East Jakarta.

Table 4. Hypothesis Test Results

\begin{tabular}{lccccc}
\hline \multicolumn{1}{c}{ Category } & $\mathbf{N}$ & Mean & $\boldsymbol{t}_{\text {count }}$ & $\boldsymbol{t}_{\mathbf{0 , 0 5}(\mathbf{5 8})}$ & Conclusion \\
\hline Experimental & 30 & 85,663 & \multirow{2}{*}{1,139} & 2,002 & \multirow{2}{*}{ Does Not Significant } \\
Control & 30 & 83,067 & & & \\
\hline
\end{tabular}

Based on the data in table above, it can be concluded that there is no significant influence on the fourth-grade students' learning outcomes of SDN Cakung Barat 07, East Jakarta using the TGT learning model assisted by the Quizizz application.

\section{Conclusion}


It can be concluded, based on the findings and discussion of this study, that the TGT learning model assisted by the Quizizz application in fourth-grade elementary school students does not show significant results. However, different results can be found in other previous studies with the same topic that discuss TGT and the Quizizz application on student learning outcomes. Such as the results by Maulidina (2018), which concluded that there was a positive influence on the fifth-grade students' science learning outcomes at SDN Tegalgede 01 Jember, using the TGT learning model [18]. Wibawa (2019) also stated positive results on using the Quizizz application on student learning outcomes in his study [19]. Therefore, using the Teams Games Tournament assisted by the Quizizz application as a learning model must still be considered due to an intention to provide a variety in the learning process.

\section{Acknowledgements}

We are grateful for the institutions' cooperation in the distribution of questionnaires by Elementary School Program Universitas Muhammadiyah Prof. DR. HAMKA. Thanks, in particular, to editor and anonymous reviewers for their useful recommendations.

\section{References}

[1] A. Sukasni and H. Efendy, "The Problematic of Education System in Indonesia and Reform Agenda,” Int. J. Educ., vol. 9, no. 3, p. 183, 2017, doi: 10.5296/ije.v9i3.11705.

[2] M. Marina, H. Indrawati, and S. Suarman, "Application of Moving Class Learning Models and Teacher Pedagogical Competence on Learning Motivation and Student Learning Discipline," J. Educ. Sci., vol. 3, no. 1, p. 72, 2019, doi: 10.31258/jes.3.1.p.72-83.

[3] I. G. A. P. Arya Wulandari, C. Sa'Dijah, A. R. As’Ari, and S. Rahardjo, "Modified Guided Discovery Model: A conceptual Framework for Designing Learning Model Using Guided Discovery to Promote Student's Analytical Thinking Skills," J. Phys. Conf. Ser., vol. 1028, no. 1, 2018, doi: 10.1088/1742-6596/1028/1/012153.

[4] O. N. Pratiwi, I. G. B. B. Nugraha, S. H. Supangkat, and B. Rahardjo, "Web application for Jigsaw-based cooperative learning," Proc. - Int. Conf. ICT Smart Soc. 2013 "Think Ecosyst. Act Converg. ICISS 2013, pp. 354-357, 2013, doi: 10.1109/ICTSS.2013.6588115.

[5] D. A. Vidhate and P. Kulkarni, "Performance enhancement of cooperative learning algorithms by improved decision making for context based application," Int. Conf. Autom. Control Dyn. Optim. Tech. ICACDOT 2016, pp. 246-252, 2017, doi: 10.1109/ICACDOT.2016.7877588.

[6] S. R. Sa'adah, "Implementation of Cooperative Learning Model with Teams Games Tournament (TGT) Method to Improve Interests and Learning Outcomes," Classr. Action Res. J., vol. 1, no. 2, pp. 65-72, 2017, doi: 10.17977/um013v1i42017p156.

[7] G. D. S. Rahayu and F. F. Nugraha, "Effect of Cooperative Learning Model Type Team Game Tournament (Tgt) on Cross-Cultural Skills in Learning Science Social Knowledge in Primary School," PrimaryEdu - J. Prim. Educ., vol. 2, no. 1, pp. 63-70, 2018, doi: 10.22460/pej.v1i1.671.

[8] A. Abidah, H. N. Hidaayatullaah, R. M. Simamora, D. Fehabutar, and L. Mutakinati, "The Impact of Covid-19 to Indonesian Education and Its Relation to the Philosophy of 
'Merdeka Belajar,"'Stud. Philos. Sci. Educ., vol. 1, no. 1, pp. 38-49, 2020, doi: 10.46627/sipose.v1i1.9.

[9] V. Dewangga, P. Ihsan, and A. Dina, "Challenges of conducting distance learning during Covid-19 pandemic: the case of Google classroom and WhatsApp," PROCEDING “Int. WEBINAR Educ. 2020", pp. 11-17, 2020.

[10] F. Zhao, "Using Quizizz to Integrate Fun Multiplayer Activity in the Accounting Classroom," Int. J. High. Educ., vol. 8, no. 1, pp. 37-43, Jan. 2019.

[11] H. Akhtar, N. Hasanati, and Istiqomah, "Game-Based Learning: Teachers' Attitude and Intention To Use Quizizz in the Learning Process," 2nd Int. Conf. Educ. Assess. Policy, no. Iceap, pp. 49-54, 2019.

[12] L. S. L. Purba, "Peningkatan Konsentrasi Belajar Mahasiswa Melalui Pemanfaatan Evaluasi Quizizz Pada Mata Kuliah Kimia Fisika I," J. Din. Pendidik., vol. 12, no. 1, pp. 29-39, 2019.

[13] A. Marvasti, "Research Methods," in The Cambridge Handbook of Social Problems, vol. 1, no. 3, Cambridge University Press, 2018, pp. 23-38.

[14] V. Mildner, "The SAGE Encyclopedia of Human Communication Sciences and Disorders Experimental Research,” SAGE Ref., pp. 728-732, 2019, doi: 10.4135/9781483380810.n242.

[15] H. White and S. Sabarwal, "Quasi-Experimental Design and Methods," no. 8.

[16] T. D. Hastjarjo, "Rancangan Eksperimen-Kuasi," Bul. Psikol., vol. 27, no. 2, pp. $187-$ 203, Dec. 2019.

[17] L. A. Palinkas, S. M. Horwitz, C. A. Green, J. P. Wisdom, N. Duan, and K. Hoagwood, "Purposeful Sampling for Qualitative Data Collection and Analysis in Mixed Method Implementation Research," Adm. Policy Ment. Heal. Ment. Heal. Serv. Res., vol. 42, no. 5, pp. 533-544, 2015, doi: 10.1007/s10488-013-0528-y.

[18] Z. Maulidina, "Pengaruh Model Pembelajaran Kooperatif Tipe Teams Games Tournament (TGT) Berbantuan Media Teka Teki Silang Terhadap Hasil Belajar Siswa di SDN Tegalgede 01 Jember," Universitas Jember, 2018.

[19] R. P. Wibawa, R. I. Astuti, and B. A. Pangestu, "Smartphone-Based Application 'quizizz' as a Learning Media,” Din. Pendidik., vol. 14, no. 2, pp. 244-253, 2019, doi: 10.15294/dp.v14i2.23359. 